\title{
Uncovering the Relationship between Entrepreneurship Training on Business Growth among SMEs in Southeast Nigeria
}

\author{
Okoli Ifeanyi E. Nuel and Anugwu Clara Chika
}

\section{ABSTRACT}

\begin{abstract}
The growth of any business is a major concern that is determined by different factors. Entrepreneurship training has been identified as one that can play a key role in the growth of SMEs around the world. The objective of this study was to examine the relationship between entrepreneurship training and business growth among SMEs in Southeast, Nigeria. A survey procedure was accepted for the study and the study was based on both secondary and primary data. The total population of this study is two hundred and fifty (250) small businesses (SMEs). Data were collected using questionnaire and analyzed using Ordinary Least Square Regression. This study revealed that entrepreneurship training has a positive impact on the business growth of the SMEs in Southeast Nigeria. The study concluded that entrepreneurship training is one of the key factors influencing SME growth, as well as the extent to which further training is based on the availability and relevance of training needs and programs. This study recommends that managers and SME owners should develop a good idea for training programs in all areas related to business to help promote and increase the competitiveness of the industry. Also, the government and all stakeholders should invest in entrepreneurship training program for creation of jobs for economic prosperity and sustainability.
\end{abstract}

Keywords: Apprenticeship, Business Growth, Competitiveness, Entrepreneurship Training, Stakeholders, Theory of planned behavior.
Submitted : January 22, 2022

Published : February 14, 2022

ISSN: $2507-1076$

DOI: $10.24018 / \mathrm{ejbmr} .2022 .7 .1 .1278$

Okoli Ifeanyi E. Nuel *

Department of Entrepreneurship Studies, Nnamdi Azikiwe University, Anambra State, Nigeria.

(e-mail: ie.okoli@unizik.edu.ng)

Anugwu Clara Chika

Department of Entrepreneurship Studies, Nnamdi Azikiwe University, Anambra State, Nigeria.

(e-mail: cc.anugwu@ ${ }^{@}$ unizik.edu.ng)

*Corresponding Author

\section{INTRODUCTION}

Small and medium enterprises (SMEs) are promoters of national economic growth and development because they play a key role in reducing poverty, increasing GDP, diversifying, and creating work in developed and developing countries. Although data is hard to obtain; Ayyagari, Demirgüç-Kunt, \& Maksimovic (2011) state that approximately $95 \%$ of businesses across the globe are SMEs, accounting for about $60 \%$ of the private sector. In addition, SMEs are critical factor in economic development, innovation, corporate restructuring as well as economic growth. Based on Poutziouris (2003), SMEs also contributes significantly to internationalization and economic development. In many countries, SMEs represent the largest and most economically viable sector. Mukulu \& Marima (2017) stated that SMEs have been recognized as a catalyst for economic, social, and political development in developed and developing countries.

In Nigeria, there are more than 37 million registered SMEs that account for about $84.02 \%$ of the total workforce, contributing $48.47 \%$ for national GDP growth as well as $7.27 \%$ in international exports (National Bureau of Statistics, 2013). Despite the overwhelming support of SMEs for economic growth in Nigeria, paucity of entrepreneurship training has become a major challenge hampering the growth of SMEs. Growth is important in SMEs survival and competitiveness, thus the success or failure of any business depends on the knowledge and understanding around the business (Anugwu, Nwosu \& Okoli, 2021). Of course, the survival of SMEs depends on their ability to participate in the market with other large companies. Business growth reduces the opportunity to close small businesses (Rauch \& Rijskik, 2013). Reinforcement is paramount not only for businesses and their owners but for all those involved since these companies bring wealth by emphasizing products and services. In Nigeria, governments at all levels are working to promote the growth of SMEs as part of a multi-year national development plan. Entrepreneurship training has been identified as one of the key strategies for the growth of SMEs (Nduta, 2016; Robb, Valerio \& Barton, 2014).

Entrepreneurship training includes the philosophy of selfreliance such as creating a new productive environment, promoting new forms of behavior and culture to meet future challenges (Arogundade, 2011). Lindh \& Thorgren (2016) opined that entrepreneurship training paves the way for entrepreneurial acceptance, improves the entrepreneur's creative potential, increases business growth, and makes entrepreneur more thoughtful. Namusonge (2006) argues that entrepreneurship training stimulates business growth as well as any SMEs that adopt entrepreneurial training have 9\% more survival rate than those without training programs. In other words, the growth of SMEs will depend on better knowledge to deliver better entrepreneurship training 
programs.

However, SMEs are essential for economic growth and thus greater mobility and prestige. Despite the importance of SMEs, research show that three out of five SMEs face stagnation or fail before the first three years of operation. Managers and entrepreneurs in many SMEs in Nigeria lack the necessary entrepreneurship training which is one of the keys to success for business competition; as such, many SMEs are unable to develop and operate effectively. Anugwu, et al., (2021) explicitly stated that a manager without requisite skills finds it difficult to come up with new ideas, think critically and explain and apply non-existent ideas to strengthen growth of firms. Furthermore, despite the large number of institutions pursuing entrepreneurship training including government agencies, higher education institutions and non-governmental organizations (NGOs), there is a lack of research on influence of the training programs on business growth of the SMEs. In light of this, the study examines the relationship between entrepreneurship training and business growth among SMEs in Southeast, Nigeria.

\section{REVIEW OF RELATED LITERATURE}

\section{A. Entrepreneurship Training}

Training is a process of gaining knowledge, skills and attitudes related to work in order to be more effective and efficient in an organization (Mullins, 2010). Effective training is useful for SMEs in a variety of forms, such as it plays an important role in building and sustaining strength, at both individual and organizational levels, and thus contributes to the organizational process change (Ezigbo, 2011). Entrepreneurship training is a structured program that aims to prepare participants with the skills and minds necessary for discovering and starting a new business (Cope, 2005; Katz, 2007). The Kauffman Foundation (2009) describes entrepreneurship training as a process of providing people with the knowledge and skills to identify opportunities that others look for rather than their understanding, selfesteem and knowledge to act where others are lagging behind. It includes firms that take advantage of opportunities to manage resources despite risks and start-ups.

The importance of entrepreneurship training has been recognized as one of the factors of SMEs growth worldwide. Entrepreneurship training promotes the creation of arts and crafts and educates people on the skills they need to be able to become self-reliant through education. One of the entrepreneurial objectives is to provide students, entrepreneurs, managers, entrepreneurs with the skills and motivation to promote entrepreneurship in any industry of their choice. Oluruntoba (2010) opines that entrepreneurship training focuses on the development, understanding and building of capacity for the pursuit of business practice, skills, and attitudes in a variety of settings. Training programs not only empower individuals but also help a team to make better use of its human resources to gain competitive advantage. Therefore, it seems important that SMEs plan for such a training program for its employees to enhance their capabilities and competencies in the workplace (Hamid, 2011).
Entrepreneurship training is designed to develop the skills, knowledge and practices that enable entrepreneurs to start a new business or expand an existing one. It has been found to be a determinant of the growth of the businesses. The performance of a business depends on many factors including internal and external factors. Entrepreneurship training is an internal factor that influences the performance of SMEs. Entrepreneurship training can be provided through a variety of methods such as apprenticeship, coaching and mentoring, peer support and participation by the subordinates. This team's work enables people to participate in the job and results in better performance, which in turn improves business growth. Entrepreneurship training not only develops the capabilities of individuals but also increases their ability to think and create in order to make better decisions in a timely and effective way (Ezigbo, 2011). Moreover, it also helps people communicate effectively with the customer and respond to their complaints in a timely manner. Entrepreneurship training develops self-efficacy and results in high performance at work, by replacing traditional weak behaviors with positive and effective work-related behaviors.

\section{B. Apprenticeship as a Type of Entrepreneurship Training}

Apprenticeship is a process by which trainees learn a trade or skill through hands-on experience while working with a skilled worker. It is further defined as an arrangement in which someone is studying a job, art or profession under another person experienced in the chosen field (Mohrenweiser \& Backes-Gellner 2010; Ogundele, Akingbade \& Akinlabi 2012). An apprentice is the one who initiates the learning process through an experienced worker. Gambin \& Hogarth (2016) argue that apprenticeship is a costeffective and effective way of influencing employees with the skills they need for their work as well as for a particular line business.

But it is unfortunate, despite its many benefits; apprenticeship is not seen as a way to career by schools (Bilau, Ajagbe, Kigbu, \& Sholanke, 2015 \& Ogundele, et al., 2012). The apprenticeship instills entrepreneurial skills and knowledge which are key requirements for the development of SMEs and makes it easier for business growth. Apprenticeship prepares and provides the entrepreneur or vocational worker with on-the-job training, thus giving him the requisite qualifications for the job at hand (Mungai, 2012). This training period depends on the type of business or trade the apprentice intends to start; thus, apprenticeship training will integrate the skills gap in the SMEs sector.

\section{Small and Medium Enterprises (SMEs) Growth}

Robson, Haugh \& Obeng (2009) stated that small and medium enterprises (SMEs) are the foundation of economic development. Because of SME's role in the national economic development of each country, countries are looking for ways to increase their economic growth through improved SMEs (Oly Ndubisi \& Iftikhar, 2012). Penrose (2006) described growth as a product of a process within a business development as well as an increase in quality and/or growth. Brush, Ceru, \& Blackburn (2009) describe growth as geographical growth, increase in numbers of branches, marketing to new customers, growth in products and services, merger, and acquisition. The growth of a firm is a result of the expansion in the demand for products or services. 
Business growth among other things, depending on the entrepreneurial spirit, the maturity of the owner, the provision of quality information, knowledge, skills as well as training in various aspects of the business (Okello-Obura \& Matovu, 2011). Similarly, the factors influencing the business growth in SMEs are entrepreneur's resources, the firm and strategy (Storey, 2014; Anugwu et.al, 2021). There are two main types of corporate growth (Dobbs \& Hamilton, 2007) internal/organic growth and external growth. Internal growth is supported by asking shareholders to provide adequate capital, or by reinventing profits into businesses that help businesses maintain healthy status. External growth, on the other hand, can be achieved through external funding, or through integration and acquisition (Edelman, Brush, \& Manolova, 2005).

Business growth is the result of good management of the equipment and capabilities that the firm uses to survive competition. For business growth, Okoli, Nnabuife \& Allison (2020) opined that entrepreneurs must be attuned to promoting firm's strategic intention and its product and services, understanding market needs and customer feedback. The development of business growth is based on the initial characteristics of the infrastructure, capabilities and learning and the way in which it is implemented and the generation of sustainable value. This is combined with research on how to access corporate and financial resources as well as what investors can be outside the issue. However, programs to prepare for entrepreneurship training to support the growth of SMEs have become another lesson. Such training should focus on filling the potential gaps of existing and new entrepreneurs. Therefore, these entrepreneurs have the necessary capacity to succeed in their various business ventures.

\section{Theoretical Underpinning}

This study is anchored in the theory of planned behaviour (TPB). This doctrine foretells man's intention to engage in behavior at a time and place. The purpose is to define all the qualities that people can display in self-control. An important part of this model is behavioral objectives; behavioural intentions affect attitude as it is more likely that the behaviour will result as well as self-assessment of the risks and benefits of the outcome. This theory states that behavioural intentions are determined by three important principles: attitudes, subjective norms, and behavioral management. Each structure has strong beliefs; these were defined as behavioural beliefs, normative beliefs, and control beliefs (Ajzen, 1991). The current study uses the theory of planned behaviour to uncover the relationship between entrepreneurship training and business growth and put to test relevance of the theory to this area of research interest in the context of SMEs in Southeast Nigeria.

\section{E. Empirical Relationship between Entrepreneurship Training and Business Growth}

Njoroge \& Gathungu (2013) examined the effect of business education and training on the development of small and medium-sized enterprises in the Githunguri district, Kenya. The study revealed that the entrepreneurs can keep simple business documents on a daily basis but are unable to make complex financial statements. Although an entrepreneur can report for market growth and profitability, as well as seem to be registering growth, lack of training and funding, system management and marketing will mean that SME will not grow beyond the initial level of company development at other levels, it will eventually collapse within the first five years of its existence. Furthermore, he found that entrepreneurs in Kenya lack real experience and expertise in areas such as business planning, financial management, strategic planning etc. as entrepreneurs want to increase their performance and improve the business.

Aun, Abdul, Oladipo \& Omotayo (2018) examined the effect of entrepreneurship skills on development of youth employment in Kwara State, Nigeria. The study population consisted of 195 students enrolled in the International Vocational, Technical \& Entrepreneurship College (IVTEC), from which a sample of 131 respondents was selected. Structured questionnaire was used for data gathering. The data were analyzed using both Pearson correlation and simple regression analysis. The results of the study showed that there is a positive relationship between the development of entrepreneurship skills and the creation of employment among youth, which is significant at a p-value of $0.000(\mathrm{R}=$ $0.714, \mathrm{R} 2=0.510,(0.000)<0.05)$. The study concluded that the development of entrepreneurship skills has an impact on youth employment.

Munene (2013) examined a study conducted in Malaysia on the impact of entrepreneurial training on small and medium-sized business development and found a positive relationship. The study found that most SMEs managers still require additional training in the areas of innovation, business accounting and sales skills. The study concluded that entrepreneurial training increases the knowledge, experience and skills required for better performance of small and medium-sized businesses. Kessy \& Temu (2010) examined the impact of training on entrepreneurs in Tanzania and concluded that business training providers have higher resources compared to an organization owned by non-training recipients.

Waithaka, Marangu \& Ng'ondu (2014) also found that the lack of seminars and conferences for SME owners was an obstacle to obtaining credit. They revealed that the lack of information on where to get professional and financial services is a major obstacle for SMEs to access credits and other resources to support their business. Entrepreneurs with higher education and management training can access information more than those without, and thus gain access to credits and other resources to improve the performance of their business. Oleforo, Oko \& Akpan (2013) examine the importance of entrepreneurship and graduate programs in South-south Nigeria. Data obtained from the study were analyzed using multiple linear regression scores with an alpha level of 0.05 . It was found that entrepreneurial training programs at the university are very important for the graduating graduates.

\section{Methodology}

This study employed the survey design plan because data for the study was collected from questionnaires from respondents. This makes the analysis process more suitable for the study. The total number used for this study consists of 
250 SMEs. Two hundred and fifty (250) SMEs from five different states comprised this survey. Complete enumeration was adopted, so there is no need to sampling. Likert's fiveitem questionnaire was used to collect data from respondents. The configuration of these coding is as follows: Agree (5), Agree (4), Undecided (3), Disagree (2) and Disagree (1). The face-to-face content of this question was first verified using split half method and the resulting number is 0.839 . Two hundred and fifty (250) copies of the questionnaire were distributed to the respondents and 240 collected representing $96 \%$ collection rate. After processing, ten copies of the questionnaire were found to be inaccurate because many of them were useless because they were not completely filled. A total of 240 positive copies of questionnaire were analyzed using the Ordinary Least Square at a 5\% (.05) level. If the pvalue obtained exceeds 0.05 , the hypothesis should be rejected but if not, the hypothesis should be accepted.

\section{A. Data Analysis}

$\mathrm{HO}_{1}$ : Entrepreneurship training is negatively related to business growth of SMEs in Southeast Nigeria.

Table 1 below shows the result of regression analysis made. As a result, it was revealed that there is a positive relationship between entrepreneurship training and business growth among SMEs in Southeast Nigeria. The coefficient of determination (R Square) indicates that $90 \%$ of the change in business growth is accounted for by change in entrepreneurship training.

TABLE I: SUMMARY OF REGRESSION BETWEEN ENTREPRENEURSHIP TRAINING AND BUSINESS GROWTH Regression Output

\begin{tabular}{ccccc}
\hline \multicolumn{5}{c}{ Dependent Variable: Business Growth } \\
\hline Model & $\mathrm{R}$ & R Square & $\begin{array}{c}\text { Adjusted R } \\
\text { Square }\end{array}$ & $\begin{array}{c}\text { Std. Error of the } \\
\text { Estimate }\end{array}$ \\
\hline 1 & $0.949^{\mathrm{a}}$ & 0.901 & 0.877 & 0.28313 \\
\hline \multicolumn{4}{l}{ Predictors: (Constant), Entrepreneurship Training }
\end{tabular}

Table II shows the ANOVA result for the relationship between entrepreneurship training and business growth among SMEs in Southeast Nigeria. The results revealed that the relationship between the variables as shown in Table 1 is the total number given by F-Statistics obtained is 1.838 , and the probability of F-Statistics is .005 . This means that the relationship does not come from chance. Hence the alternative hypothesis that states that entrepreneurship training is positively related to the business growth among small and medium-sized enterprises (SMEs) in Southeast Nigeria.

TABLE II: SUMMARY OF ANOVA BETWEEN ENTREPRENEURSHIP TRAINING AND BUSINESS GROWTH

\begin{tabular}{ccccccc}
\hline \multicolumn{7}{c}{ ANOVA $^{\mathrm{a}}$} \\
\hline \multirow{2}{*}{ Model } & Regression & 0.952 & 239 & 0.190 & 1.838 & $0.005^{\mathrm{a}}$ \\
& Square & Df & $\begin{array}{c}\text { Mean } \\
\text { Square }\end{array}$ & F & Sig. \\
\hline & Residual & 0.104 & 1 & 0.104 & & \\
\hline & Total & 1.056 & 240 & & & \\
\hline
\end{tabular}

a. Predictors: (Constant), Entrepreneurship Training.

b. Dependent Variable: Business growth.

\section{DISCUSSION AND RECOMMENDATIONS}

The results of this study provide extensive training for businesses in maximizing profitability and industry growth.
The finding of the hypothesis test shows that there is a positive relationship between entrepreneurship training and business growth. It also shows that $90 \%$ of the business growth is explained by changes in entrepreneurship training. That is, the more entrepreneurial training is lacking among owners/managers of SMEs, the greater the likelihood that the business growth will not come. The result of this existing study indicates that entrepreneurial training has a significant positive relationship with business growth among SMEs in Southeast Nigeria. The results lend support on the view that entrepreneurship training is positively related to the business growth among SMEs in Southeast Nigeria. This finding is in agreement with the research of Njoroge \& Gathungu (2013), Munene (2013) and Aun, Abdul, Oladipo \& Omotayo (2018).

Having reviewed literature and rigorous research related to entrepreneurship training and business growth, the results of the study have made it clear that entrepreneurship training is a key factor in the growth of SMEs. Thus, the extent to which further training is based depends on the availability and the effectiveness of training needs and programs. Specifically, with consistent training, solid growth should improve. As a result, the owner/manager trained will put in the expertise, knowledge, and ability to improve productivity, efficiency and commitment and will therefore provide quality services to the clients of the organizations.

Based on the results of this study, the following recommendations are given:

1) Managers and SME owners should develop a good idea for training programs in all areas related to business to help promote and increase the competitiveness of the industry.

2) The government and all stakeholders should invest in entrepreneurship training programs. The creativity and sustenance of these programs are beneficial not only for entrepreneurs but also the economy as a whole because the societal resources will be raised, and jobs created all for economic growth and sustainability.

\section{REFERENCES}

Ajzen, I. (1991). The theory of planned behavior: Organizational Behavior and Human Decision Processes, 50.

Anugwu, C.C., Nwosu K.C. \& Okoli, I.E.N. (2021). Effect of Organizational Capability on Firms Growth: Implications on SMEs in Anambra State, Nigeria. European Journal of Business and Management Research, 6(5), 1-5. DOI:10.24018/ejbmr.2021.6.5.1050.

Arogundade, B.B. (2011). Entrepreneurship education: An imperative for sustainable development in Nigeria. Journal of Emerging Trends in Educational Research and Policy Studies, 2(1), 26-29.

Aun, I.I, Abdul, F.A, Oladipo, G.T. \& Omotayo, O.O. (2018). Effect on Entrepreneurship Skills Development on Youth Employment in Kwara State, Nigeria. Journal of Economics and Business Research, 2, 125150.

Ayyagari, M., Demirgüç-Kunt, A. \& Maksimovic, V. (2011). Small vs. young firms across the world: contribution to employment, job creation, and growth. World Bank Policy Research Working Paper, (5631).

Bilau, A. A., Ajagbe, A. M., Kigbu, H., \& Sholanke, A.B. (2015). Review of shortage of skilled craftsmen in small and medium construction firms in Nigeria. Journal of Environment and Earth Science, 5(15).

Brush, C.G., Ceru, D.J., \& Blackburn, R. (2009). Pathways to entrepreneurial growth: the influence of management, marketing, and money. Business Horizons, 52(5), 481-491. http://dx.doi.org/10.1016/j. bushor.2009.05.003.

Cope, J. (2005). Toward a dynamic learning perspective of entrepreneurship. Entrepreneurship Theory Practice. 29, 373-397. 
doi:10.1111/j.1540-6520.2005.00090.x.

Dobbs, M., \& Hamilton, R.T. (2007). Small business growth: Recent evidence and new directions. International Journal of Entrepreneurial Behavior \& Research, 13(5), 296- 322.

Edelman, L.F., Brush, C.G., \&Manolova, T. (2005). Co-alignment in the resource-performance relationship: Strategy as mediator. Journal of Business Venturing, 20(3), 359-383.

Ezigbo, C.A. (2011). Advanced Management: Theory and Applications, Enugu: Immaculate Publications Limited.

Gambin, L., \& Hogarth, T. (2016). The costs and benefits of apprenticeships to employers: policy, funding and training quality. In Human resource management, innovation and performance (80-94). Palgrave Macmillan, London.

Hamid, S. (2011). A study of effectiveness of training and development programmes of UPSTDG, India - An Analysis, South.

Katz, J.A. (2007). "Education and training in entrepreneurship," in The Psychology of Entrepreneurship, eds J. R. Baum, M. Frese, and R. Baron (Mahwah, NJ: Lawrence Erlbaum Associates, Inc.), 209-235.

Kauffman Foundation (2009). Entrepreneurship education. Retrieved on $28^{\text {th }}$ March 2021 from https/www.google.com.

Kessy, S. \& Temu, S.S. (2010). The impact of training on performance of micro and small Enterprises served by Microfinance Institutions in Tanzania. Research Journal of Business Management.

Lindh, I., \& Thorgren, S. (2016). Entrepreneurship education: the role of local business. Entrepreneurship \& Regional Development, 28(5-6) 313-336.

Mohrenweiser, J., \& Backes-Gellner, U. (2010). Apprenticeship training: for investment or substitution? International Journal of Manpower, 31(5), 545-562.

Mukulu, E. \& Marima, M.M. (2017). Role of Entrepreneurship Training in Growth of Micro and Small Enterprises in Kiambu County. Saudi Journal of Business and Management Studies, 532-543. DOI: $10.21276 /$ sjbms.

Munene, B.G. (2013). Impact of Entrepreneurial Training on Performance of Micro, Small and Medium Enterprises in Nakuru County. Nairobi.

Mungai, B. (2012). The Relationship Between Business Management Training and Small \& Medium Sized Enterprises' Growth in Kenya. Nairobi: Thesis Kenyatta University.

Namusonge, M. (2006). The role of entrepreneurship, education and training in stimulating entrepreneurial careers. In 3rd International Entrepreneurship Conference organized by United States International University (USIU), Nairobi.

National Bureau of Statistics (NBS) (2013). SMEs contribution to national economic growth, N.B.S. statistics, Editor 2013, National Bureau of Statistics: Nigeria.

Ndirangu, A.N., \& Mukulu, E. (2014). Effects of entrepreneurial training content on the growth of micro and small enterprises in Kangemi, Nairobi. The International Journal of Business \&Management, 2 (8), 85-91.

Nduta, K.M. (2016). Influence of entrepreneurial training on business growth of small and medium enterprises among youth driven initiatives in Nairobi County, Kenya.

Njoroge, C.W., \& Gathungu, J.M. (2013). The Effect of Entrepreneurial Education and Training on Development of Small and Medium Size Enterprises in Githunguri District-Kenya. International Journal of Education and Research, 1(8), 1-22.

Nyachome, P. (2012). Factors influencing the effectiveness of entrepreneurship training programmes: a case of financial knowledge for Africa, Kenya. Unpublished MBA project, University of Nairobi, Nairobi: Kenya.

Ogundele, M.O., Sofoluwe, A.O., \& Kayode, D.J. (2012). Integrating entrepreneurship skills acquisition in to the National Youths Service Corps (NYSC) Programme in Nigeria. Journal of Entrepreneurship and Management. 1(3), 24-28.

Ogundele, O.J.K., Waidi, A.A. \& Hammed, B.A. (2012). Entrepreneurship training and education as strategic tools for poverty alleviation in Nigeria. American International Journal of Contemporary Research, 2 (1):148-156

Okello-Obura, C., \& Matovu, J. (2011). SMEs and business information provision strategies: Analytical perspective. Library philosophy and practice. $\quad$ http://webpages.uidaho.edu/-mbolin/okello-oburamatova.htm

Okoli, I.E.N., Nnabuife, E.K. \& Allison P.U. (2020). Critical Success Factors for SMEs Performance: Empirical Evidence. International Journal of Advanced Academic Research (Social and Management Sciences), 6 , (12) doi: 10.46654/ij.24889849.s6122.

Oleforo, N.A, Oko, D.O. \& Akpan, E.G. (2013). Entrepreneurship Training Programme in Universities and Graduates' Productivity in South-South Nigeria. International Education Studies; 6, (7), 260-266. Doi:10.5539/ies.v6n7p260.
Oluruntoba, S. (2010). Entrepreneurship education crucial to tackling graduates unemployment- Excerpts. Retrieved from www.google.com.ng on $19^{\text {th }}$ March, 2021

Oly Ndubisi, N., \& Iftikhar, K. (2012). Relationship between entrepreneurship, innovation and performance: Comparing small and medium-size enterprises. Journal of Research in Marketing and entrepreneurship, 14(2), 214-236.

Penrose, E. (2006). A teoria do crescimento da firma. Campinas: Editora da Unicamp.

Poutziouris, P. (2003). The strategic orientation of owner-managers of small ventures: evidence from the UK small business economy. International Journal of Entrepreneurial Behavior \& Research, 9(5): 185-214.

Rauch, A. \& Rijskik, S.A. (2013). The effects of general and specific human capital on long-term growth and failure of newly founded businesses. Entrepreneurship Theory and Practice (3), 923-941.

Robb, A., Valerio, A., \& Barton, B. (2014). Entrepreneurship education and training: Insights from Ghana, Kenya, and Mozambique. World Bank Publications.

Robson, P.J., Haugh, H.M., \& Obeng, B.A. (2009). Entrepreneurship and innovation in Ghana: enterprising Africa. Small Business Economics 32(3), 331-350.

Waithaka, T., Marangu, W.N., \& Ng'ondu, C.N. (2014). Entrepreneurial development by microfinance institutions effect on the growth of micro and small enterprises in Nairobi Central Business District: A case of Jitegemea Credit Scheme, Nairobi, Kenya. European Journal of Business and Management, 6, 177-186. 